\section{Self-rated health and working conditions among workers from primary health care centers in Brazil}

\author{
Auto-avaliação de saúde e condições de trabalho \\ entre trabalhadores de centros de atenção \\ primária à saúde no Brasil
}

1 Instituto de Pesquisa Econômica Aplicada Brasília, Brasil.

2 Universidade do Vale do Itajaí, Itajaí, Brasil.

${ }^{3}$ Faculdade de Medicina, Universidade Federal de

Pelotas, Pelotas, Brasil.

Correspondence D. A. Höfelmann Universidade do Vale do Itajaí.

Rua Uruguai 458, Itajaí, SC 88302-202, Brasil. doroaph@yahoo.com.br

\begin{abstract}
This cross-sectional study with 1,249 workers from all 49 municipal primary health care centers was conducted in Florianópolis, Santa Catarina State, Brazil, with the objective of investigating the prevalence of poor self-rated health and its association with working conditions and other factors. Multivariate statistical analyses were conducted using Poisson regression. The prevalence of poor self-rated health was $21.86 \%$ (95\%CI: 19.56\%-24.15\%). The largest prevalence was found among dental assistants (35.71\%), and the lowest among physicians (10.66\%). In the adjusted analysis, the outcome was associated with female gender ( $P R=1.48$; 95\%CI: 1.032.14), older age ( $P R=1.29 ; 95 \% C I: 1.05-1.59)$, higher education ( $P R=0.69$; 95\%CI: 0.55-0.87), more time working at the primary care center $(P R=1.57 ; 95 \% C I: 1.29-1.98)$, higher workload score ( $P R=1.67 ; 95 \% C I: 1.35-2.05)$, obesity $(P R=$ 1.74; 95\%CI: 1.37-2.21), and often or always experiencing musculoskeletal symptoms ( $P R=$ 2.69; 95\%CI: 1.90-3.83). A higher workload score remained associated with the outcome, suggesting an association between working conditions and self-rated health.
\end{abstract}

Self-Rated Health; Working Conditions; Health Personnel; Primary Health Care
Leila Posenato Garcia 1 Doroteia Aparecida Höfelmann 2 Luiz Augusto Facchini 3

\section{Introduction}

In the last three decades, self-rated health has been broadly used as an indicator in psychosocial and gerontological research, as well as in epidemiologic surveys. Research systematically emphasizes its reliability and predictive power, and demonstrates its association with several morbidity and mortality measures, even after adjusting for other variables, such as measures of physical health, age, gender, life satisfaction and income, among others 1 .

The factors associated with self-rated health have been broadly studied 2. Gender, age, socioeconomic, occupational and environment factors ${ }^{3}$, access to healthcare and other variables 2 can influence self-rated health.

A longitudinal study about self-rated health among employees demonstrated its explanatory potential for health and socioeconomic inequalities 4 . Borg \& Kristensen 5 observed, among Danish employees, that approximately two-thirds of the social gradient with regard to worsening of self-rated health could be explained by work environment and lifestyle factors.

In Brazil, over 2.5 million workers are employed in the health care sector. The public sector employs $56.4 \%$ of them, and $68.8 \%$ of these work in administrative positions at the city level 6 . It should be emphasized that these figures apply only to formal jobs; workers in precarious employment are not included. There are there- 
fore over one million healthcare workers at the city administration level in Brazil, most of whom work at primary health care centers.

There is increasing recognition that both patient safety and access to high quality healthcare is linked to the well-being of healthcare workers 7. Injuries and disabilities among healthcare workers affect the quality of healthcare delivery 8 .

The aims of this cross-sectional study are to investigate the prevalence of poor self-rated health and its association with working conditions, adjusting for socio-demographical, occupational, behavioral and health-related variables among primary health care workers in Florianópolis, South Brazil.

\section{Methods}

This cross-sectional study aimed to investigate all workers from Primary Healthcare Centers from the Health Department of the city of Florianópolis, the capital of Santa Catarina State in southern Brazil. There are 49 Primary Healthcare Centers in the city, divided in five Health Districts (Downtown, East, North, South, and Continent), where there were 1,332 workers at the time of data collection.

Workers from all occupations participated in this study, including nurses, physicians, dentists, other university level professionals (social work- ers, speech therapists, psychologists, pharmacists, and nutritionists), administrative personnel, receptionists, nurse technicians, nurse assistants, dental assistants, housekeepers, health community agents, security guards and drivers.

Data were collected between October 2006 and December 2006, through standardized questionnaires that were previously tested. Questionnaires were administered by trained interviewers.

The outcome variable, self-rated health, was collected through the question: "How would you rate your health?”. Interviewers read the possible answers and the participants rated their health as excellent, very good, good, fair, or poor. For the analysis, the variable was dichotomized, considering poor self-rated health to be a grouping of the categories fair and poor.

The exposure variables included socio-demographical, occupational, behavioral and healthrelated variables (Figure 1).

Work loads were collected separately as present or absent (excessive workload, constant attention required, fast work, repetition, non-creative work, intense work, monotony). Afterwards, a score was generated, considered high when at least four items were present and low otherwise.

Working environment conditions were collected separately as adequate or inadequate (lighting, temperature, airing, workplace size, noise, cleanliness, furniture, building mainte-

Figure 1

Hierarchic analysis model.

\begin{tabular}{|c|c|c|}
\hline 1st level & \multicolumn{2}{|c|}{$\begin{array}{c}\text { Socio-demographical variables } \\
\text { Sex } \\
\text { Age } \\
\text { Education } \\
\text { Marital status } \\
\text { Skin color }\end{array}$} \\
\hline $2^{\text {nd }}$ level & \multicolumn{2}{|c|}{$\begin{array}{c}\text { Occupational variables } \\
\text { Employment regimen } \\
\text { Length of employment for the city administration } \\
\text { Work load score } \\
\text { Work environment conditions } \\
\text { Occupational accidents in the previous year } \\
\text { Occupation }\end{array}$} \\
\hline $3^{\text {nd }}$ level & $\begin{array}{l}\text { Behavioral variables } \\
\text { Job satisfaction }\end{array}$ & $\begin{array}{l}\text { Health-related variables } \\
\text { Current smoking } \\
\text { Obesity } \\
\text { Musculoskeletal symptoms }\end{array}$ \\
\hline & \multicolumn{2}{|c|}{ Self-rated health } \\
\hline
\end{tabular}


nance, unpleasant smells). A score for work environment conditions was created, being inadequate when at least five inadequate conditions were present.

The body mass index, calculated using the formulae weight/(height)2, was dichotomized as obese or not. A subject was considered obese when the body mass index was above $30 \mathrm{~kg} / \mathrm{m}^{2}$.

Musculoskeletal symptoms were collected through the Nordic Musculoskeletal Questionnaire 10 and the language validated for Brazilian Portuguese 11 . The respondents were asked to report the frequency with which they experienced pain or discomfort in the previous 12 months in ten anatomic sites: neck, shoulders, elbows, hands/wrists, thoracic spine, lumbar spine, thighs, knees, lower legs and ankles. For the analysis, musculoskeletal symptoms were dichotomized as never or rarely experiencing symptoms, or often or always experiencing symptoms.

Data entry was carried out using Epidata version 3.1 (Epidata Association, Odense, Denmark) with double entry and validation. Statistical analyses were conducted with Stata 9.0 software (Stata Corp., College Station, U.S.A.). After description, a bivariate analysis was conducted to estimate differences among proportions, using Fisher's exact test for categorical exposure variables and the linear trend test for ordinal ones. The multivariate analysis, through Poisson regression with robust variance, was oriented by the hierarchic model shown in Figure 1, using backwards regression level by level. Variables that presented association to the outcome with $\mathrm{p}$-value $\leq 0.20$ were kept in the model, with the aim of controlling for possible confounding. Confidence intervals (95\%) were calculated. Associations with $\mathrm{p}$-value $\leq 0.05$ were considered statistically significant.

The questionnaires didn't identify the workers who provided information, what preserved data anonymity. The study was conducted according to the ethical principles embodied in the Declaration of Helsinki and received approval from the Ethics Review Board at the School of Medicine of the Federal University of Pelotas.

\section{Results}

A total of 1,249 workers were interviewed (93.35\%). Table 1 presents the absolute and relative frequencies of the variables studied. The prevalence of poor self-rated health (regular or poor) was $21.86 \%$ (95\%CI: $19.56 \%-24.15 \%)$. The mean age of the workers was 37.42 (16-73) and the median was 37 years-of-age. Most of them were women (83.59\%). A quarter (24.98\%) of the workers had a university degree. The mean em- ployment time within the city administration was 72.08 months (0-372) and the median was 48 months. The predominant employment regimen was outsourced (49.56\%). Most of the workers had a high workload score (59.73\%), and $42.55 \%$ had an inadequate score of working conditions. Approximately two-thirds of the workers reported always or frequently experiencing musculoskeletal symptoms (67.89\%). One-third (32.75\%) were current smokers and $10.93 \%$ were obese.

Figure 2 shows the prevalence of poor selfrated health according to occupation. The highest prevalence was found among dental assistants $(35.71 \%)$ and the lowest among physicians (10.66\%). For this reason, occupation was dichotomized as physician or others.

Table 2 presents crude and adjusted analyses of the association between self-rated health and socio-demographical, occupational, behavioral and health-related variables. In the crude analysis, poor self-rated health was positively associated with female gender, higher age, lowest education, more time working for the city administration, higher workload score, a poor working environment, occupation other than physician, obesity, often or always experiencing musculoskeletal symptoms, and job satisfaction. Marital status, skin color, employment regimen, occupational accident in the previous year, and current smoking were not found to have a statistical association with self-rated health $(\mathrm{p}>0.05)$.

After the adjusted analysis, poor self-rated health remained associated with female gender, older age, higher education, more time working in municipal primary healthcare, a higher work load score, obesity, and often or always experiencing musculoskeletal symptoms. Work environment, occupation and job satisfaction lost statistical significance after adjusted analysis.

In the adjusted analysis, the variable most strongly associated with poor self-rated health was musculoskeletal symptoms. Workers presenting musculoskeletal symptoms had a $169 \%$ higher risk of evaluating poorly their health than those who did not report musculoskeletal symptoms.

\section{Discussion}

The prevalence of poor self-rated health in this study was $21.86 \%$, higher than that observed in a study among Danish workers (16.5\%) 5 . Lower prevalences were also found among industrial workers in Santa Catarina State, the same state where the present study was conducted $(15.6 \% 12$ and $16.6 \% 13)$. However, the prevalence was similar to the Brazilian population between 14 and 64 
Table 1

Number of observations and frequencies in the categories of the studied variables among primary health care workers $(n=1,249)$. Florianópolis, Santa Catarina State, Brazil, 2006.

\begin{tabular}{|c|c|c|}
\hline & $n$ * & $\%$ \\
\hline \multicolumn{3}{|l|}{ Self-rated health } \\
\hline Positive & 976 & 78.14 \\
\hline Negative & 273 & 21.86 \\
\hline \multicolumn{3}{|l|}{ Sex } \\
\hline Female & 1,044 & 83.59 \\
\hline Male & 205 & 16.41 \\
\hline \multicolumn{3}{|l|}{ Age (years) } \\
\hline$<38$ & 633 & 50.72 \\
\hline$\geq 38$ & 615 & 49.28 \\
\hline \multicolumn{3}{|l|}{ Education } \\
\hline Primary & 286 & 22.90 \\
\hline Intermediary & 651 & 52.12 \\
\hline University-level & 312 & 24.98 \\
\hline \multicolumn{3}{|l|}{ Marital status } \\
\hline Married or living with a partner & 464 & 37.18 \\
\hline Single & 784 & 62.82 \\
\hline \multicolumn{3}{|l|}{ Skin color } \\
\hline White & 954 & 76.38 \\
\hline Non-white & 295 & 23.62 \\
\hline \multicolumn{3}{|l|}{ Employment regimen } \\
\hline Permanent & 445 & 35.63 \\
\hline Temporary & 185 & 14.81 \\
\hline Outsourced & 619 & 49.56 \\
\hline \multicolumn{3}{|l|}{ Length of employment (years) } \\
\hline$\leq 2$ & 655 & 52.44 \\
\hline$>2$ & 594 & 47.56 \\
\hline \multicolumn{3}{|l|}{ Work load score } \\
\hline High & 746 & 59.73 \\
\hline Low & 503 & 40.27 \\
\hline \multicolumn{3}{|l|}{ Work environment conditions } \\
\hline Adequate & 698 & 57.45 \\
\hline Inadequate & 517 & 42.55 \\
\hline \multicolumn{3}{|l|}{ Occupational accident in the previous year } \\
\hline No & 967 & 77.42 \\
\hline Yes & 282 & 22.58 \\
\hline \multicolumn{3}{|l|}{ Occupation } \\
\hline Physician & 122 & 9.77 \\
\hline Community health worker & 504 & 40.35 \\
\hline Nurse assistant & 213 & 17.05 \\
\hline Administrative staff & 134 & 10.73 \\
\hline Nurse & 83 & 6.65 \\
\hline Cleaning staff & 69 & 5.52 \\
\hline Dentist & 58 & 4.64 \\
\hline Dental assistant & 28 & 2.24 \\
\hline Security guard and driver & 21 & 1.68 \\
\hline Other university-level occupation ** & 17 & 1.36 \\
\hline \multicolumn{3}{|l|}{ Physician } \\
\hline Yes & 122 & 9.77 \\
\hline No & 1,127 & 90.23 \\
\hline
\end{tabular}

(continues) 
Table 1 (continued)

n* $\%$

\begin{tabular}{lcc}
\hline Current smoking & & \\
No & 840 & 67.25 \\
Yes & 409 & 32.75 \\
Obesity & & 89.07 \\
No & 1,059 & 10.93 \\
Yes & 130 & \\
Musculoskeletal symptoms & & 32.11 \\
No & 401 & 67.89 \\
Yes & 848 & 11.53 \\
Job satisfaction & & 88.47 \\
No & 144 & \\
Yes & 1,105 & \\
\hline
\end{tabular}

* Number of valid observations;

** Social workers, speech therapists, psychologists, pharmacists, and nutritionists.

Figure 2

Prevalence of poor self-rated health among primary health care workers $(n=1,249)$. Florianópolis, Santa Catarina State, Brazil, 2006.

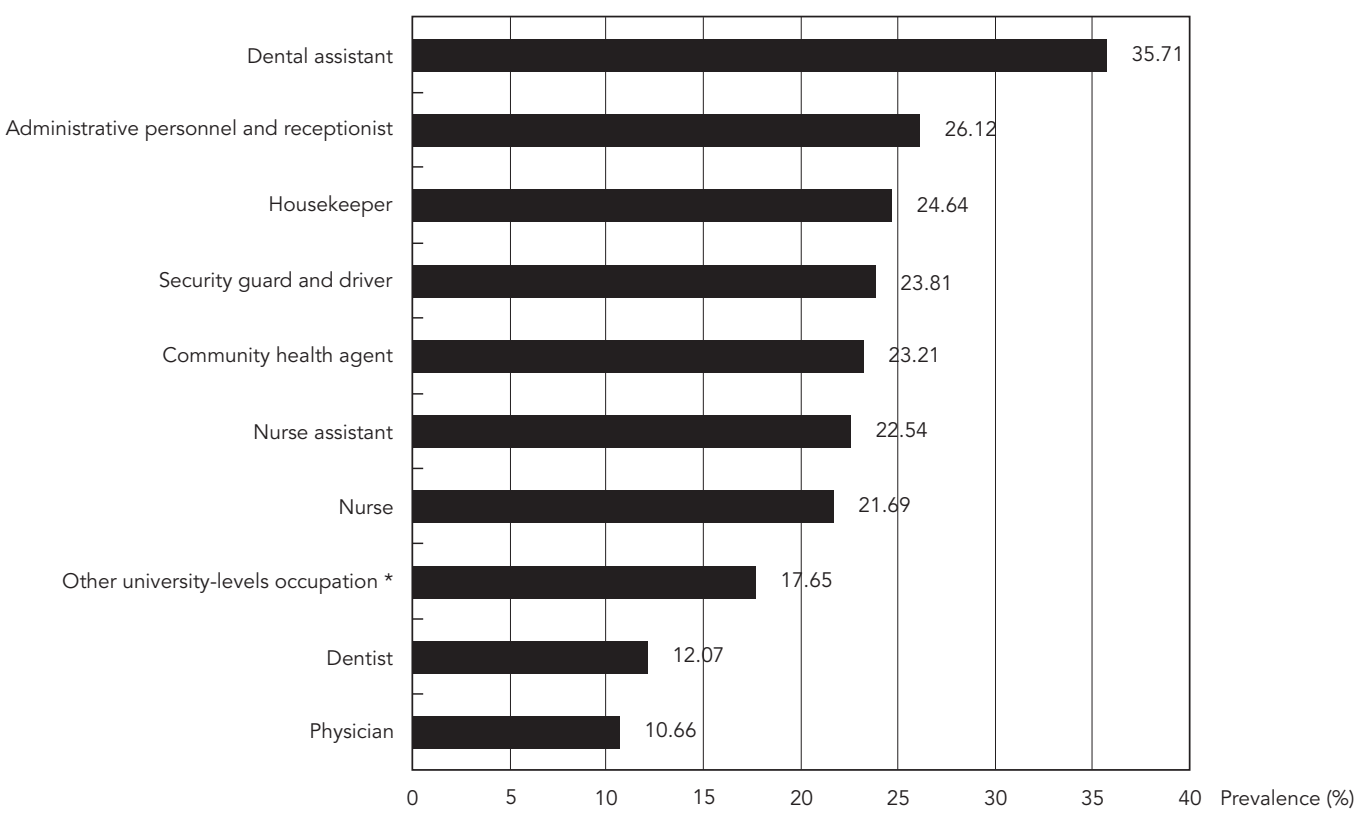

\footnotetext{
* Social workers, speech therapists, psychologists, pharmacists and nutritionists.
} 
Table 2

Crude and adjusted analysis, through Poisson regression, of the association between poor self-rated health and socio-demographic, occupational, behavioral and health-related variables among primary health care workers $(n=1,249)$. Florianópolis, Santa Catarina State, Brazil, 2006.

\begin{tabular}{|c|c|c|c|c|c|}
\hline \multirow[t]{2}{*}{ Variables } & \multirow[t]{2}{*}{ Prevalence (\%) } & \multicolumn{2}{|c|}{ Crude analysis } & \multicolumn{2}{|c|}{ Adjusted analysis * } \\
\hline & & PR $(95 \% \mathrm{Cl})$ & $\mathrm{p}$-value & PR $(95 \% \mathrm{Cl})$ & $\mathrm{p}$-value ** \\
\hline Sex & & & $0.003 * * *$ & & 0.034 \\
\hline Female & 23.37 & 1.0 & & 1.0 & \\
\hline Male & 14.15 & $1.65(1.16-2.36)$ & & $1.48(1.03-2.14)$ & \\
\hline Age (years) & & & $0.019 * \star \star$ & & 0.017 \\
\hline$<38$ & 19.12 & 1.0 & & 1.0 & \\
\hline$\geq 38$ & 24.72 & $1.29(1.05-1.59)$ & & $1.29(1.05-1.59)$ & \\
\hline Education & & & $<0.001 \#$ & & $<0.001$ \\
\hline Primary & 31.12 & 1.0 & & 1.0 & \\
\hline Intermediary & 20.74 & $0.67(0.51-0.87)$ & & $0.69(0.55-0.87)$ & \\
\hline University-level & 15.71 & $0.50(0.35-0.72)$ & & $0,55(0,40-0,75)$ & \\
\hline Marital status & & & $0.321 * * *$ & & 0.275 \\
\hline Married or living with a partner & 20.26 & 1.0 & & 1.0 & \\
\hline Single & 22.83 & $1.13(0.90-1.41)$ & & $1.13(0.91-1.42)$ & \\
\hline Skin color & & & 0.126 *** & & 0.269 \\
\hline White & 20.86 & 1.0 & & 1.0 & \\
\hline Non-white & 25.08 & $1.20(0.95-1.52)$ & & $1.14(0.90-1.44)$ & \\
\hline Employment regimen & & & $0.353 * \star \star$ & & 0.404 \\
\hline Permanent & 23.37 & 1.0 & & 1.0 & \\
\hline Temporary & 14.59 & $0.62(0.41-0.95)$ & & $0.78(0.52-1.17)$ & \\
\hline Outsourced & 22.94 & $0.98(0.76-1.26)$ & & $1.02(0.78-1.33)$ & \\
\hline Length of employment (years) & & & $<0.001 * \star \star$ & & $<0.001$ \\
\hline$\leq 2$ & 16.18 & 1.0 & & 1.0 & \\
\hline$>2$ & 28.11 & $1.74(1.39-2.16)$ & & $1.57(1.24-1.98)$ & \\
\hline Work load score & & & $<0.001 * \star \star$ & & $<0.001$ \\
\hline High & 16.76 & 1.0 & & 1.0 & \\
\hline Low & 29.42 & $1.76(1.42-2.17)$ & & $1.67(1.35-2.05)$ & \\
\hline Work environment conditions & & & 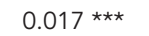 & & 0.075 \\
\hline Adequate & 19.48 & 1.0 & & 1.0 & \\
\hline Inadequate & 25.34 & $1.30(1.05-1.60)$ & & $1.21(0.98-1.49)$ & \\
\hline Occupational accident in the previous year & & & $0.101 * \star \star$ & & 0.382 \\
\hline No & 20.79 & 1.0 & & 1.0 & \\
\hline Yes & 25.53 & $1.23(0.97-1.55)$ & & $1.11(0.88-1.40)$ & \\
\hline Occupation & & & $0.001 * \star \star$ & & 0.106 \\
\hline Physician & 10.66 & 1.0 & & 1.0 & \\
\hline Other & 23.07 & $2.17(1.28-3.65)$ & & $1.64(0.90-2.98)$ & \\
\hline Current smoking & & & $0.942 * \star \star$ & & 0.497 \\
\hline No & 21.79 & 1.0 & & 1.0 & \\
\hline Yes & 22.00 & $1.01(0.81-1.26)$ & & $0.93(0.74-1.15)$ & \\
\hline Obesity & & & $<0.001 * \star \star$ & & $<0.001$ \\
\hline No & 19.17 & 1.0 & & 1.0 & \\
\hline Yes & 43.08 & $2.25(1.78-2.84)$ & & $1.74(1.37-2.21)$ & \\
\hline Musculoskeletal symptoms & & & $<0.001 * \star *$ & & $<0.001$ \\
\hline No & 8.73 & 1.0 & & 1.0 & \\
\hline Yes & 28.07 & $3.22(2.30-4.49)$ & & $2.69(1.90-3.83)$ & \\
\hline Job satisfaction & & & $0.009 * \star \star$ & & 0.108 \\
\hline No & 20.72 & 1.0 & & 1.0 & \\
\hline Yes & 30.56 & $1.47(1.12-1.94)$ & & $1.28(0.95-1.73)$ & \\
\hline
\end{tabular}

PR: prevalence ratio; 95\%Cl: 95\% confidence intervals.

* Poisson regression with robust variance, adjusted for sex, age, education, time working for the city administration, work load score, work environment conditions, occupation, obesity and musculoskeletal symptoms;

** Heterogeneity test;

*** Two-tailed Fisher's exact test;

\# Linear trend test. 
years of age $(22.12 \%)$ 14. Among Greek nurses, a higher prevalence was reported (58\%) 15 .

There are many factors that could explain the differences among negative self-rated health prevalences. The outcome variable can be collected and categorized in different ways. In the present study, self-rated health was collected in five categories, and negative self-rated health included the two lowest ones (fair and poor). Among Greek nurses, five categories were used (excellent, good, fair, poor and very poor health) but the three lowest ones were grouped 15 . This difference may also explain why the prevalence of negative self-rated health among Greek nurses was twice that observed in this study.

In addition, differences in the population structure, related to gender, age, income, education and other distal variables could change the prevalence and factors associated with the outcome 1.

Those populations in which men predominate tend to exhibit lower prevalences of poor self-rated health 13 . The association between female gender and poorer self-rated health, observed among primary health-care workers, was also found in other studies 14,16. Among female workers, double-shift work, not accounted for in several studies, strengthens the adverse effects related to poor self-rated health, including psychological distress, pain complaints, and fatigue 16 .

Evidences from longitudinal studies indicate that manual work, lower education and lower socioeconomic levels are associated with selfrated health degradation during the course of life 2,5. Furthermore, a lower educational level predicts subsequent negative changes in selfrated health 17 . Dachs \& Santos 14 found that the main determinant of self-rated health is socioeconomic status, and highlighted the role of education as mediator for ensuring that socioeconomic levels can influence the outcome.

In Brazil, education is clearly associated with better income and working conditions 14 . Studies systematically showed better self-rated health among workers with higher social status 18,19 . In the present study, the crude analysis showed that the risk of negative self-rated health was doubled among non-medical occupations. In the adjusted analysis, this association lost its statistical significance.

In this study, length of employment remained associated to the outcome, even after adjusting for other variables. Martinez \& Latorre 20 also observed that shorter length of employment was associated with greater work capacity and higher job satisfaction. However, unlike in other studies 21,22 , unstable employment wasn't associated with poor self-rated health in this study.
The prevalence of poor self-rated health was higher among the oldest. This association can be largely explained by the functional limitations of chronic diseases, related to the aging process 23 .

Other studies also showed an association between obesity and negative self-rated health 24,25 , also among workers 5,17,19. Obesity is associated with non-communicable chronic diseases, and even in the absence of such diseases, it remains associated with negative self-rated health 25 . Work limitations and the discrimination related to obesity could strengthen this association, mainly among women with higher education and income levels, considering the social and professional status value given to thinness 26 .

In spite of the understanding of health as a value that goes beyond physical well being, the variable with the greatest impact upon self-rated health was the experience of musculoskeletal symptoms, related to the biomedical concept of health. However, psychosocial aspects can be clearly observed. The experience of pain and disease involves complex meanings, including social reactions, material deprivation, trauma, stress, restrictions to daily activities and/or work, fear and expectations from the disease. Besides that, the frequent presence of pain presents an association with self-rated health 27 .

Workload remained associated to the outcome even after the adjusted analysis. Borg \& Christensen 5 , in a prospective study with 5,001 Danish workers, between 18-59 years of age, observed that the occupational variables had a more pronounced association with self-rated health than the lifestyle ones.

The work-health relationship should be studied to help understand how disease expresses itself as a social process, aiming to propose interventions to promote workers' health ${ }^{28}$. Several studies listed the exposure to a variety of factors that influence healthcare workers' wellbeing, satisfaction, safety, and quality of care for patients, such as musculoskeletal problems, violence, psychosocial and organizational factors including psychological stress and shift work, and infectious disease exposures 29 .

In the case of primary health care workers, who are responsible for providing health care to the community, work-related distress compromises work performance and the quality of care 7 .

The subjective health assessment reflects a person's integrated perception of health, including its biological, psychological and social dimensions, which are inaccessible to any external observer. On the contrary, self-reported diseases mainly reflect the medical dimensions of health, which can be objectively assessed. Subjective assessments of global health could be even more 
sensitive in health monitoring than external measures of health. In addition, standardized self-reported surveys of health status are easy to administer and inexpensive to process 30 .

On the other hand, the use of self-reported health measures should be interpreted with caution, since individuals exposed to environments where diseases and/or health hazards are common tend to evaluate their health more positively 31 .

In this study, all variables were self-reported, so information bias can be present. The crosssectional design precluded the inference of cause-effect relationships. It can't be determined if the associated variables behaved as a cause or consequence of the outcome. In this way, longitudinal studies are recommended to provide a better understanding of the causal direction of the findings. There is always a possibility of residual confounding due to the existence of unmeasured variables.

Recognizing primary healthcare as fundamental to the effectiveness of healthcare policies, primary healthcare workers and healthcare work itself have been subjects of recent studies 32 . However, studies on the health of primary healthcare workers are still scarce in Brazil, which reinforces the relevance of the present study.

In conclusion, the multidimensional structure of self-rated health, confirmed in this study, highlights that the workers' health actions should be interdisciplinary, based on the view of the worker as a whole subject.

\section{Resumo}

Estudo transversal com 1.249 trabalhadores dos 49 centros municipais de atenção primária à saúde de Florianópolis, Santa Catarina, Brasil, objetivou investigar a prevalência de auto-avaliação de saúde ruim e sua associação com condições de trabalho e outros fatores. A prevalência de auto-avaliação de saúde ruim foi de 21,86\% (IC95\%: 19,56\%-24,15\%). A maior prevalência foi observada entre assistentes odontológi$\cos (35,71 \%)$ e a mais baixa entre os médicos $(10,66 \%)$. Após análise ajustada, o desfecho permaneceu associado com: gênero feminino ( $R P=1,48$; IC95\%: 1,03-2,14), maior idade $(R P=1,29$; IC95\%: 1,05-1,59), maior esco- laridade ( $R P=0,69$; IC95\%: 0,55-0,87), maior tempo de trabalho na atenção primária municipal $(R P=1,57$; IC95\%: 1,29-1,98), elevada carga de trabalho ( $R P=$ 1,67; IC95\%: 1,35-2,05), obesidade ( $R P=1,74$; IC95\%: 1,37-2,21) e sintomas músculo-esqueléticos freqüentes ( $R P=2,69$; IC95\%: 1,90-3,83). Um elevado escore de carga de trabalho permaneceu associado com o desfecho, o que sugere uma associação entre condições de trabalho e auto-avaliação de saúde.

Auto-Avaliação de Saúde; Condições de Trabalho; Pessoal de Saúde; Atenção Primária à Saúde 


\section{Contributors}

D. A. Höfelmann contributed in the analysis of data and writing of the article. L. P. Garcia participated in the study design, supervision and data collection, writing of the article, and data analysis. L. A. Facchini participated in the study design and writing of the article.

\section{Acknowledgments}

The authors wish to thank the Municipal Health Department of the city of Florianópolis, Santa Catarina State, Brazil, and all the workers who participated in the study.

\section{References}

1. Idler EL, Benyamini Y. Self-rated health and mortality: a review of twenty-seven community studies. J Health Soc Behav 1997; 38:21-37.

2. Kelleher CC, Friel S, Nic Gabhainn S, Tay JB. Sociodemographic predictors of self-rated health in the Republic of Ireland: findings from the National Survey on Lifestyle, Attitudes and Nutrition, SLAN. Soc Sci Med 2003; 57:477-86.

3. Rahkonen O, Laaksonen M, Martikainen P, Roos E, Lahelma E. Job control, job demands, or social class? The impact of working conditions on the relation between social class and health. J Epidemiol Community Health 2006; 60:50-4.

4. Singh-Manoux A, Ferrie JE, Lynch JW, Marmot M. The role of cognitive ability (intelligence) in explaining the association between socioeconomic position and health: evidence from the Whitehall II prospective cohort study. Am J Epidemiol 2005; 161:831-9.

5. Borg V, Christensen TS. Social class and self-rated health: can the gradient be explained by differences in life style or work environment? Soc Sci Med 2000; 51:1019-30.

6. Instituto Brasileiro de Geografia e Estatística. Estatísticas de saúde: atenção à saúde 2005. Rio de Janeiro: Instituto Brasileiro de Geografia e Estatística; 2006.
7. Yassi A, Hancock T. Patient safety - worker safety: building a culture of safety to improve healthcare worker and patient well-being. Healthc Q 2005; 8:32-8.

8. Alamgir H, Cvitkovich Y, Yu S, Yassi A. Work-related injury among direct care occupations in British Columbia, Canada. Occup Environ Med 2007; 64:769-75.

9. World Health Organization. Obesity: preventing and managing the global epidemic. Report of the WHO Consultation of Obesity. Geneva: World Health Organization; 1997.

10. Kuorinka I, Jonsson B, Kilbom A, Vintenberg H, Biering-Sprensen F, Andersson G. Nordic questionnaires for the analysis of musculoskeletal symptoms. Appl Ergon 1987; 18:233-7.

11. Pinheiro FA, Tróccoli BT, Carvalho CV. Validação do Questionário Nórdico de Sintomas Osteomusculares como medida de morbidade. Rev Saúde Pública 2002; 36:307-12.

12. Barros MV, Nahas MV. Comportamentos de risco, auto-avaliação do nível de saúde e percepção de estresse entre trabalhadores da indústria. Rev Saúde Pública 2001; 35:554-63.

13. Höfelmann DA, Blank N. Auto-avaliação de saúde entre trabalhadores de uma indústria no sul do Brasil. Rev Saúde Pública 2007; 41:777-87. 
14. Dachs JNW, Santos APR. Health self-rating in Brazil: analysis of data of the PNAD/2003. Ciênc Saúde Coletiva 2006; 11:887-94.

15. Pappas NA, Alamanos Y, Dimoliatis IDK. Self-rated health, work characteristics and health related behaviours among nurses in Greece: a cross-sectional study. BMC Nursing 2005; 4(8).

16. Walters V, McDonough P, Strohschein L. The influence of work, household structure, and material resources on gender differences in health: an analysis of the 1994 Canadian National Population Health Survey. Soc Sci Med 2002; 54:677-92.

17. Froom P, Melamed S, Triber I, Ratson NZ, Hermoni D. Predicting self-reported health: the CORDIS study. Prev Med 2004; 39:419-23.

18. Blank N, Diderichsen F. Social inequalities in the experience of illness in Sweden: a "double suffering". Scand J Soc Med 1996; 24:81-9.

19. Mansson N-O, Merlo J. The relation between selfrated health, socioeconomic status, body mass index and disability pension among middle-aged men. Eur J Epidemiol 2001; 17:65-9.

20. Martinez MC, Latorre MRDO. Health and work ability among office workers. Rev Saúde Pública 2006; 40:851-8.

21. Virtanen M, Kivimaki M, Elovainio M, Vahtera J. Selection from fixed term to permanent employment: a prospective study on health, job satisfaction, and behavioural risks. J Epidemiol Community Health 2002; 56:693-9.

22. Ferrie JE, Shipley MJ, Stansfeld SA, Marmot MG. Effects of chronic insecurity and change in job security on self reported health, minor psychiatric morbidity, physiological measures, and health related behaviours in British civil servants: the Whitehall II Study. J Epidemiol Community Health 2002; 56:450-4.

23. Manderbacka K, Lundberg O, Martikainen P. Do risk factors and health behaviours contribute to self-ratings of health? Soc Sci Med 1999; 48:1713-20.
24. Osler M, Heitmann BL, Hoidrup S, Jorgensen LM Schroll M. Food intake patterns, self rated health and mortality in Danish men and women. J Epidemiol Community Health 2001; 55:399-403.

25. Okosun IS, Choi S, Matamoros T, Dever A. Obesity is associated with reduced self-rated general health status: evidence from a representative sample of white, black and Hispanic Americans. Prev Med 2001; 32:429-36

26. Paquette MC, Raine K. Sociocultural context of women's body image. Soc Sci Med 2004; 59 : 1047-58.

27. Mäntyselkä PT, Turunen JHO, Ahonen RS, Kumpusalo EA. Chronic pain and poor self-rated health. JAMA 2003; 290:2435-42.

28. Laurell AC, Noriega M. Processo de produção e saúde: trabalho e desgaste operário. São Paulo: Editora Hucitec; 1989.

29. Lundstrom T, Pugliese G, Bartley J, Cox J, Guither C. Organizational and environmental factors that affect worker health and safety and patient outcomes. Am J Infect Control 2002; 30:93-106.

30. Miilumpalo S, Vuori I, Oja P, Pasanen M, Urponen H. Self-rated health status as a health measure: the predictive value of self-reported health status on the use of physician services and on mortality in the working-age population. J Clin Epidemiol 1997; 50:517-28.

31. Sen A. Health: perception versus observation. BMJ 2002; 324:860-1

32. Facchini LA, Piccini RX, Tomasi E, Thumé E, Silveira DS, SiqueiraI FV, et al. Performance of the PSF in the Brazilian South and Northeast: institutional and epidemiological assessment of primary health care. Ciênc Saúde Coletiva 2006; 11:669-81.

Submitted on 11/Mar/2009

Final version resubmitted on 22/Oct/2009

Approved on 18/Dec/2009 